\title{
Exchange New Product News
}

Journal of Derivatives \& Hedge Funds (2007) 13, 263-270. doi:10.1057/palgrave.jdhf.1850077

\section{DEUTSCHE BÖRSE LAUNCHES EFFICIENCY PROGRAMME AND RESUMES SHARE BUYBACKS}

Deutsche Börse has decided to implement an efficiency programme targeting $€ 100$ million cost savings per annum. The programme is focused on optimising operational costs while retaining planned investments in future growth. The programme is expected to have a significant positive impact of $€ 50$ million on operational costs from 2008. The full potential of the programme will be realised from 2010 onwards. Total restructuring charges to achieve these cost savings will amount to $€ 50$ million - these will be fully provisioned in 2007.

As a result, Deutsche Börse has set a guidance for total costs in 2008 of $€ 1,130$ million. The cost guidance for 2008 compares to an estimated total cost base for 2007 of $€ 1,200$ million, before the above-mentioned restructuring charges for the efficiency programme of $€ 50$ million. All costs exclude consolidation of the International Securities Exchange (ISE). Closing of the ISE transaction is expected in Q4/2007.

Deutsche Börse also decided on a revised financing concept for the ISE acquisition, with a view to further optimising its capital structure and resuming its share buyback programme with immediate effect. Based on this revised financing concept, Deutsche Börse plans to issue some $€ 1.5$ billion in long-term debt and hybrid bonds, compared to $€ 1.3$ billion under the initial structure. The revised financing concept is based on a management announcement of the credit metrics stated below, but not contingent on a change of Deutsche Börse's legal and organisational structure as foreseen by the original concept.

Given the higher amount of long-term debt/ hybrid financing for ISE under the revised financing concept, a significant amount of the accumulated earnings in the current year are no longer necessary to finance the ISE acquisition. This in combination with the very strong operational performance of the company enables Deutsche Börse to resume its share buyback programme immediately. For the remainder of financial year 2007, Deutsche Börse plans a share buyback volume of around $€ 300$ million.

Deutsche Börse continues to explore formats to further improve its capital structure and plans to give further guidance on its midterm capital structure and earnings distribution goals at its Annual Results Conference on 20th February, 2008.

\section{Targeted credit metrics}

In the context of the revised financing concept for the ISE acquisition - while recognising that ratings are based on a variety of factors Deutsche Börse has decided to support Clearstream's current 'AA' rating credentials through the targeting of a 'consolidated EBITDA to Interest Expense ratio' — so-called 
interest coverage ratio - of at least 16 times. In calculating the group's interest coverage ratio, the company will include 50 per cent of any coupons on hybrid debt with an equity credit from the rating agencies of 50 per cent or higher. Furthermore, in view of Clearstream's 'AA' rating objective, Deutsche Börse believes it is important to maintain certain minimum levels of tangible equity (currently $€ 700$ million at Clearstream International S.A. and $€ 250$ million at Clearstream Banking S.A. with subordinated profit participation rights issued by Clearstream Banking S.A. to Deutsche Börse AG of $€ 150$ million also in place).

The management of the company, therefore, dedicates its efforts to keeping the interest coverage, the tangible equity and subordinated profit participation rights of its controlled subsidiaries Clearstream International S.A. and Clearstream Banking S.A. at these levels in order to maintain key metrics that the company understands are consistent with an 'A' rating on Clearstream.

\section{Share buyback}

Deutsche Börse resumed its share repurchase programme on 20th September, 2007. The company will use the current authorisation by its shareholders to repurchase up to 10 per cent of its share capital amounting to a nominal $€ 200$ million, while taking into account shares owned by the company. The company currently holds $5,682,738$ own shares in treasury. Furthermore, the buyback up until 31st December, 2007 is limited to a number of shares equivalent to an overall purchase price of up to $€ 300$ million. It is anticipated to cancel the repurchased shares and to reduce the share capital of the company accordingly, and to use the repurchased shares for employee share programmes and/or for obligations eventually arising from debt financial instruments exchangeable into equity instruments.

The shares will be repurchased exclusively on the exchange. The purchase price for the shares to be repurchased may neither exceed nor fall short of the volume-weighted average share price for the five trading days prior to the purchase commitment by more than 10 per cent. The relevant prices for determining the volumeweighted average are the closing auction prices for Deutsche Börse shares in electronic Xetra trading at the Frankfurt Stock Exchange (FWB).

Deutsche Börse will instruct its agent to use its best efforts to buy back no more than 25 per cent of the daily trading volume on any one day. Additionally, the agent will be bound by agreement to uphold the trading rules set forth in Article 5 of Commission Regulation (EC) No. 2273/2003 of 22nd December, 2003. In particular, no more than 25 per cent of the average daily trading volume of the shares in the month prior to publication of the repurchase programme may be repurchased in any one day.

\section{FOUR NEW LYXOR ETFS LAUNCHED IN THE XTF SEGMENT ON XETRA}

Deutsche Börse has further expanded its XTF segment for listed index funds on the electronic trading platform Xetra. Four more exchangetraded funds (ETFs) issued by Lyxor Asset Management have been tradable in XTF.

Three of the four new index funds track emerging markets indices. The Lyxor ETF MSCI Emerging Markets (ISIN: FR0010429068) allows investors to participate in the performance of the MSCI Emerging Markets Index. The index represents around 85 
per cent of the total market capitalisation of global emerging markets. Lyxor also offers an ETF on the MSCI EM Latin America Index (FR0010410266) for investors who want to participate in the performance of Latin American emerging markets in particular. This index is comprised of listed companies from Argentina, Brazil, Chile, Colombia, Mexico and Peru. Finally, investors can use the Lyxor ETF South Africa (ISIN: FR0010464446) to make targeted investments in around 40 South African companies listed on the Johannesburg Stock Exchange. The ETF is based on the FTSE/JSE Top 40 Index. All three emerging markets ETFs are offered at an annual management fee of 0.65 per cent.

In addition to the emerging markets ETFs, investors put their money on a DJ EURO STOXX 50 Index with a double leverage feature using the Lyxor ETF Leveraged DJ EURO STOXX 50 (ISIN: FR0010468983): if, for example, the index rises by 2 per cent, the index fund gains 4 per cent, with the leverage effect working the same way in the opposite direction. The annual management fee for the ETF amounts to 0.4 per cent. All of the funds distribute dividends on an annual basis.

\section{SCENARIO CALCULATION FOR DEUTSCHE BÖRSE EQUITY INDICES: CHANGES EFFECTIVE FROM 24 SEPTEMBER}

From 24 September, new index weights apply for companies in the equity indices of Deutsche Börse.

Changes in the equity indices MDAX ${ }^{\circledR}$, SDAX $^{\circledR}$ and TecDAX ${ }^{\circledR}$ will take effect on 24 September. Tognum will be included in MDAX and will replace Patrizia Immobilien. The share of Patrizia Immobilien will move to SDAX, replacing the share of DAB Bank. Wacker Construction will also be included in SDAX, replacing Loewe. In TecDAX, the share of Versatel will be included. Jenoptic will be leaving the Index.

The next equity index review is scheduled for 5th December, 2007.

Deutsche Börse has additionally reviewed its families for international indices and strategy indices. Changes in these indices are also effective from 24 September.

\section{EUREX REPO CREATES THE FIRST PAN-EUROPEAN MARKET FOR COLLATERALISED MONEY MARKET TRANSACTIONS}

Eurex Repo, the electronic repo market of the international derivatives exchange Eurex, has internationalised its Euro GC Pooling offering with European collaterals, thus becoming the first electronic market in Europe to enable crossborder liquidity management via a wide range of ECB-eligible collateral.

As of 3 September, the scale of available securities holdings for Euro GC Pooling transactions will be extended to include Eurobonds and a wide range of European bonds in addition to German bonds. The collateral basket can also be used as collateral for refinancing within the framework of ECB open market transactions.

This enhancement of automated straightthrough processing (STP) in managing securities holdings for Euro GC Pooling transactions is possible through the connection of Clearstream Banking Frankfurt (CBF) and Clearstream Banking Luxembourg (CBL). All Clearstream's 
customers will be able to use more than 8,000 securities as collateral in Euro GC Pooling.

In August 2007, the daily average outstanding volume in Euro GC Pooling peaked at $€ 17$ billion. The average annual growth rate has totalled 48 per cent since it was launched in March 2005. Twenty Eurex Repo participants are currently active in this segment. Euro GC Pooling also enables the settlement of high-volume transactions, and has already processed individual transactions in excess of $€ 10$ billion.

\section{NEW COMMODITY ETF TRADABLE IN XTF SEGMENT ON XETRA: INDEXCHANGE LAUNCHES WORLD'S FIRST ETF ON DJ AIG COMMODITY INDEX}

A new exchange traded fund issued by Indexchange Investment AG is now tradable in Deutsche Börse's XTF segment.

The Dow Jones AIG Commodity Swap EX (ISIN: DE000A0H0728) is the world's first ETF to track the performance of the Dow Jones AIG commodity index. The index currently comprises 19 commodities that are weighted primarily based on trading activity and global production volumes; the maximum weighting per commodity is 15 per cent and the minimum is two per cent. The 19 commodities are aluminium, cotton, petrol, natural gas, gold, heating oil, coffee, copper, cattle, lean hogs, corn, nickel, crude oil, silver, soy beans, soy bean oil, wheat, zinc and sugar.

The Dow Jones AIG Commodity Swap EX tracks the total return version of the DJ-AIGCI and offers investors simple and inexpensive access to the commodities market with an annual management fee of 0.45 per cent.

\section{STRUCTURED PRODUCTS EXCHANGE NAMED 'SCOACH': JOINT VENTURE BETWEEN DEUTSCHE BÖRSE AND SWX GROUP OPERATES UNDER A NEW NAME FROM 1st SEPTEMBER, 2007}

The structured products joint venture between the SWX Group and Deutsche Börse will in future be known as 'Scoach'. The new name was announced by both partners on 14 August.

To date, the exchange has operated in Switzerland under the name SWX Quotematch Ltd and in Germany as Börse Frankfurt Smart Trading AG. Scoach is expected to become Europe's leading structured products exchange, and further extends the flourishing partnership between the SWX Group and Deutsche Börse in the world's number one futures exchange Eurex and the pan-European index provider STOXX.

Scoach focuses on the fast-growing structured products segment (certificates, investment and leverage products). It was launched successfully on 1st January, 2007 and has since achieved record trading volumes, gaining market share in both its home markets.

April 2008 will see Scoach migrate trading in structured products on the German market to Deutsche Börse's modern, high-performance Xetra platform. In doing so, Scoach will be adding more than 100 foreign trading participants and thus reaching retail customers from all over Europe.

\section{DEUTSCHE BÖRSE LAUNCHES TWO NEW DAXGLOBAL INDICES}

Deutsche Börse is expanding its DAXglobal ${ }^{\circledR}$ international index family to include two new 
indices: the DAXglobal Agribusiness Index allows investors to invest in companies from the agricultural sector, while the new DAXglobal Nuclear Energy Index enables investments in the nuclear energy segment.

The DAXglobal Agribusiness Index tracks the performance of the world's 40 leading agricultural firms. These companies must generate more than 50 per cent of their sales revenue in the agricultural sector, while the stocks are selected on the basis of market capitalisation and stock exchange turnover. The stocks in the index are chosen from the following agricultural sub-sectors: the keeping and processing of farm animals, the production of seed and fertiliser, diversified agricultural groups and the production and marketing of ethanol and biodiesel. The index is a response to the growing demand for higher quality agricultural products, as well as the increasing global demand for bioethanol, the production volume of which, according to a study by the Organization for Economic Cooperation and Development (OECD), is set to double over the next few years.

The DAXglobal Nuclear Energy Index contains the 40 largest and most liquid companies from the nuclear energy sector. The stocks are weighted on the basis of market capitalisation and stock exchange turnover. The index tracks the following sub-sectors: energy production, the transport of nuclear material, uranium production, enrichment and storage, and the construction of nuclear power stations and nuclear facilities.

Both indices are adjusted on a quarterly basis and are calculated in EUR, USD and GBP. The composition is reviewed every year in September. Individual stocks are capped at 8 per cent.

\section{ISE SHAREHOLDERS APPROVE COMBINATION WITH EUREX: FURTHER STEP IN CREATING THE LEADING TRANSATLANTIC DERIVATIVES MARKETPLACE}

Shareholders of International Securities

Exchange (ISE) voted to approve the merger agreement of ISE and Eurex which, upon completion, will create the leading transatlantic derivatives marketplace. At a special shareholders meeting in New York, 99.7 per cent of the stockholders who voted were in favour of the agreement. More than 67 per cent of eligible shares were voted. Under the terms of the agreement, Eurex will pay ISE shareholders USD 67.50 in cash for each ISE share held. The combination will be implemented by way of a merger between ISE and a subsidiary of US Exchange Holdings Inc., itself a Eurex subsidiary.

The affirmative shareholder vote and antitrust clearance by the US Department of Justice obtained in May satisfy two conditions to the closing of the transaction. The merger still requires approval by the US Securities and Exchange Commission. Eurex and ISE expect to close the transaction in Q4/2007 as anticipated at the time of the announcement on 30 April.

The combination of Eurex and ISE will create the leading transatlantic derivatives marketplace with a combined overall trading volume of 2.1 billion contracts in 2006. The combination will have a broad USD and Euro denominated product coverage as well as significant operations and revenues in both the US and Europe. It will further strengthen Eurex's position as a leading global derivatives marketplace and will create the undisputed market leader in equity, equity index and long-term interest rate derivatives 
worldwide. Eurex's and ISE's complementary member bases and product portfolios provide significant growth opportunities across asset classes and national boundaries. Further upside potential stems from joint product and business development opportunities.

\section{EUREX EXPANDS OFFER OF EUROPEAN EQUITY OPTIONS}

Eurex has expanded its range of European equity options and the segment will be complemented by one Dutch and three French underlyings. The new options are on Air France, Alstom and Vallourec (France), and Randstad (Netherlands). This step further completes coverage of the respective national benchmark indices CAC40 and AEX with Eurex equity options, as all four underlyings are constituents of the respective blue chip indices.

The French and Dutch equity option segments on Eurex have performed well. Together, the equity options of the two segments have achieved a volume of around 11.5 million contracts this year in comparison to 9.4 million for the same period in 2006. During the first six months, the 'Dutch Equity Options' segment recorded an average daily volume of approximately 52,000 contracts (2006: 38,500 contracts), while the 'French Equity Options'segment traded approximately 38,000 contracts (2006: 28,400 contracts). Open interest is currently at approximately 5.2 million contracts.

The contract specifications of the new options are analogous to the existing French and Dutch equity options. As of 1 August, the four new options will also be included in the marketmaking package for French and Dutch equity options.

\section{EUREX LAUNCHES TRADING IN AUSTRIAN EQUITY OPTIONS}

The international derivatives exchange Eurex has expanded its European equity option offering, introducing 11 options on Austrian equities from 10 September: BoehlerUddeholm, Betandwin, Erste Bank, Immoeast, ÖMV, Raiffeisenbank, RHI, Telekom Austria, Verbundgesellschaft, Voestalpine and Wienerberger. With the exception of Immoeast, all of the underlying shares are listed in the Austrian blue chip index ATX. The new options will complement the ten single stock futures on selected Austrian equities that have been listed since 2006.

The new options represent a further step towards the coverage of main European markets. Demand for the new options will come from fund managers and proprietary traders, as well as from issuers of warrants and certificates.

The contract specifications are the same as those for the existing German equity options. A contract comprises 100 shares, and is offered with a maturity of up to 24 months. Eurex is waiving the trading fees until the end of November 2007. At the same time, a marketmaking model for Austrian equity options will support liquidity from the outset. Participants can also settle transactions executed offexchange using the OTC functions offered by Eurex Clearing AG.

\section{AVOX CHOSEN BY SWIFT TO MAINTAIN FINANCIAL INDUSTRY BIC DATABASE}

Avox, the leading counterparty data verification network, announced today that it was chosen by SWIFT, the global financial cooperative, for the 
cleansing and maintenance of data records in its BIC (Bank Identification Code) database. Under the three-year agreement, Avox will be instrumental in empowering SWIFT's business entity reference data quality and universal identification for the benefit of the financial community.

The BIC database contains the fundamental information required for unique business entity identification, which consists of the company's name and the registered address. The BIC database enhancements will enable SWIFT's 8,100-plus customers to increase their reliance on the content and participate in the update notification process for improved data quality and timeliness. Ultimately, both SWIFT users and Avox customers will benefit from an increased amount of stress-tested data.

\section{LEADING HEDGE FUND MANAGERS ANNOUNCE INDUSTRY REVIEW OF BEST PRACTICE}

Leading hedge fund managers today announce the formation of a working group to review best practice and to examine the application of industry-wide standards where appropriate.

The high-level working group will consult widely and will focus particularly on practices in the areas of valuation, disclosure and risk management. The group will look at existing principles, standards and guidelines, evaluate areas that may require strengthening and suggest solutions that may include adherence to voluntary standards.

This is a UK-based initiative and the working group will be working within the context of the Financial Services Authority's principles-based environment. It is supported by the leading hedge fund managers in Europe and has the support of the international trade body for the industry, the Alternative Investment Management Association (AIMA).

Sir Andrew Large, formerly deputy governor of the Bank of England and chairman of the UK financial regulator, will lead the working group, which includes 13 hedge fund managers, of which 11 are UK-based. The working group members are:

Brevan Howard - Nagi Kawkabani, CEO

Brummer \& Partners - Klaus Jäntti, CEO

Centaurus Capital - Bernard Oppetit, CEO

Cheyne Capital - Stuart Fiertz, President

CQS - Michael Hintze, CEO

Gartmore - Jeffrey Meyer, CEO

GLG - Manny Roman, co-CEO

Lansdowne Partners - Paul Ruddock, CEO

London Diversified - Rob Standing,

Founding Partner

Man Group - Stanley Fink, Deputy

Chairman

Marshall Wace - Paul Marshall, Chairman

Och-Ziff Capital Management - Michael

Cohen, Managing Partner, CIO of Europe

RAB Capital - Michael Alen-Buckley, Chairman

In addition to the members of the working group, other leading London-based hedge fund managers have expressed support for this industry-led initiative.

\section{EQUIFAX TO TACKLE RISING APPLICATION AND IDENTITY FRAUD}

Equifax, the leading credit information and fraud prevention service provider, believes that the continued growth in credit application and identity fraud reinforces the urgent need for the lending industry to step up its defences against 
this crime by sharing data on previous applications and frauds.

According to KPMG, financial firms lost ten times more to fraud in 2005 than in 2004. Furthermore, CIFAS, UK's Fraud Prevention Service, reported that identity fraud attempts have risen 17 per cent in Q1 2006 compared to Q1 2005 and application fraud losses rose by 13 per cent in 2005 compared to 2004.

Equifax is taking the lead in addressing this continuing threat to the consumer credit industry by creating an industry-wide database of previous application frauds and developing an online fraud prevention solution that will be accessible as an integral part of the credit application process.

The new solution will incorporate Sira Financial from Synectics Solutions Ltd and will enable organisations to manage their own bespoke fraud rules, and prioritise and manage their own operational workflows.

\section{SIGNIFICANT ENHANCEMENTS TO SFE SPI $200^{\mathrm{TM}}$ FUTURES AND OPTIONS}

The Sydney Futures Exchange (SFE) is pleased to announce the addition of serial futures to the SPI product suite. Commencing 1st September, 2006, two serial month futures will be available at all times in addition to the six quarterly expiry months (March, June, September, December) currently available.
Also, the expiry of serial month options will be aligned to the expiry of the serial month futures so that both serial month futures and options expire on the third Thursday of the settlement month at 12:00pm.

The listing of serial month SFE SPI $200^{\mathrm{TM}}$ Futures and alignment of serial month SFE SPI $200^{\mathrm{TM}}$ Options to the respective serial month SFE SPI $200^{\mathrm{TM}}$ Futures will bring a number of benefits to users. For instance:

- Additional futures expiry months will allow hedgers to select the month that best fits their investment timeframe, thereby reducing basis risk.

— 'In-the-money' serial month option positions taken to expiry will receive a cashsettled future that expires at the same time as the option. This means that serial month options will be effectively cash settled. This allows for easier administration of serial option positions taken to expiry compared to the current process where 'in-the-money' serial month option positions receive a futures position in the next financial quarter month.

- Removal of Pin Risk. Writers of serial options will no longer incur risks associated with serial SFE SPI $200^{\mathrm{TM}}$ Futures closing at the strike price on expiration, for example, uncertainty as to whether an option will be exercised by the holder. 